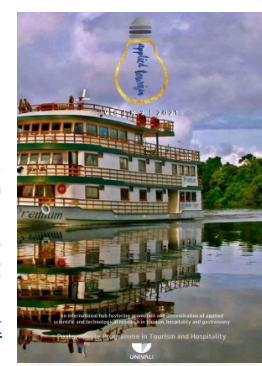

Artigo Científico

\title{
CONSERVATION UNITS IN AMAZONAS: A BRIEF REFLECTION RELATED TO THE ANAVILHANAS NATIONAL PARK
}

\author{
Rúbia Silene Alegre Ferreira ${ }^{a}$ \\ Edileuza Lobato da Cunhab \\ Luiz Carlos da Silva Flores ${ }^{c}$
}

\begin{abstract}
Given the importance of strengthening reflections on Conservation Units (UC's) in the Amazon, the present study proposes a discussion on the Parks of the state of Amazonas, as well as a brief reflection related to the Anavilhanas National Park. In the first moment, the number of parks and their spheres of national, state and municipal management is presented. Then, the considerations are turned to the Anavilhanas National Park and its peculiarities. The methodology used consists of a bibliographic review around this theme, as well as the use of information from the Institutions that work directly in the area. As a result, the natural supply of parks represents a potential ally in terms of preserving resources and developing sustainable ecotourism activities. Anavilhanas Park is a national conservation unit, known worldwide, which presents the necessary attractions for sustainable ecotourism, since, since its recognition, as a protected area, it has been generating positive results for this follow-up.
\end{abstract}

\section{Keywords:}

Conservation Units

Parks of Amazonas

Anavilhanas 


\section{INTRODUCTION}

The state of Amazonas is a unit of the Brazilian federation that presents several complexities in its territory. It has 62 municipalities, distributed in four mesoregions and 13 microregions, it is the largest in territorial extension, however, with the smallest number of population per square kilometer. This quantity of cities, the capital Manaus is responsible for a relative proportion of the economic performance of the state.

As a result, more than fifty percent of the population, from the more than 3.483.985 inhabitants of the state, 1.802.014 resided in Manaus, according with the Brazilian Institute of Geography and Statistics (IBGE). Still according with the population estimates of the IBGE, from the implantation of the Manaus Free Trade Zone, the population growth of this city was notedly modified, as seen in the Censuses: 311.622 (1970); 633.383 (1980); 1.011 .501 (1991); 1.405 .835 (2000); 1.802 .014 (2010) and 2.219.580 in $2020^{1}$.

The growth process in the cities is a phenomenon that directly impacts the environment in its surroundings, because when the population migrates and swells in a given location And in this habit the city grows, but not necessarily as a result of planning, but as an effect of occupations of areas that ended up losing their potential as result of the depredation of the environment and human action.

The act of creating or transforming areas with potential for animals, living beings, water resources, among other endowments in protected areas, represents an advance in Brazilian legislation. As the State imposes limits on human occupation, in these areas, grow the possibilities for continuing the journey towards the objectives of maintaining these natural resources.

The justification for choosing the object of study is in function to the capacity of natural offer that the state of Amazonas has in its biodiversity. In this sense, the parks are the locations that concentrate, in a given territoriality, the magnitude of these natural riches and the Anavilhanas National Park, since its creation as a protected area presents this configuration. Adding to that it is important to highlight that in its surroundings there is a local community where its residents work as tour and trail drivers, fishermen, cooks, waiters, canoeists, among other functions that produce income for this community. Besides the issues pertaining to the Park's own natural resources, there

${ }^{1}$ BGE Automatic Recovery System - SIDRA. Recovered from (https:// sidra.ibge.gov.br/home/pimpfbr/brasil) is an interaction towards the parties involved in its preservation.

The name of the Park originates from a corruption of the name of the river Aneuene or Anauini, which also was called Anaviana, word very close to the current Anavilhanas. In addition to this origin, there is another indication that the name Anavilhanas would be related to ships, due to the navigability of the Negro River. In this way, the National Park received the name of Anavilhanas because the name of the archipelago that it protects, according to ICMBio (2017); Nogueira-Neto (1991) \& Pinto (1894).

Thus, the present study proposes a discussion about the Parks of the state of Amazonas, as well as a brief reflection related to the Anavilhanas National Park. In the first moment, is presented the quantitative of parks and their spheres of national, state and municipal management. Then, the considerations are turned to the Anavilhanas National Park and its peculiarities.

Researches dedicated to this theme are welcome to the academic community, as they point out the correlation between the theories related to sustainability, ecotourism and the natural offerings of Amazonas, as natural endowments. To the public management, this type of research signals clues as to what can be improved and direct the management of these endowments, as factors of possible ways of contributing to regional development.

In addition to this introduction, the structure of the work is presented as follows: the theoretical framework discusses the issue related to Conservation Units (UC's) and Parks. The subsequent section highlights the methodology used to achieve the proposed objective. The discussion of the results presents, in the first part, the potential in parks in Amazonas, at the national, state and municipal spheres. In the second, the focus rests on Anavilhanas and finally, the final considerations are presented.

\section{CONSERVATION UNITS}

\section{The parks}

Ecological Thought passed through several currents until it reached the current discussions. However, still prevails the dichotomous counterpoint between preserving and guaranteeing environmental reproduction, and appropriating nature in favor of progress, according to Chaves (2016).

Theoretical discussions, arising from problems presented in society and in nature, contributed to give shape to the norms aimed at protecting the environment, and subsequently shaped the typologies of natural areas. These visions culminated in currents and discussions that influenced and are reflected in Federal Law 9.985, of June 18, 2000, that instituted the National 
System of Conservation Units (SNUC).

This System divides the Conservation Units (UC) into two modalities: Integral Protection Units and Sustainable Use Units. As the name explicit, Integral Protection Units are fully protected areas, in which only the indirect use of their natural resources is allowed, without the permanence of human beings. In the second case, there is a requirement to conserve natural resources, admitting human permanence and the direct use of its natural resources in a sustainable manner according to Chaves (2016).

The article $4^{\circ}$, of Law $n^{\circ} 9.985 / 2000$ establishes the objectives of the Conservation Units, among which can be highlighted in MMA (2002):

IV - promoting sustainable development based on natural resources;

$\mathrm{VI}$ - protect natural and slightly altered landscapes of remarkable scenic beauty;

VII - protect the relevant characteristics of a geological, geomorphological, speleological, archaeological, paleontological and cultural nature;

XII - favor conditions and promote environmental education and interpretation, recreation in contact with nature and ecological tourism.

The cited objectives, in addition to the concern with the conservation and protection of the environment, are directly related to the tourist activity, specifically with the ecotourism practices. According to Rodrigues \& Abrucio $(2019$, p. 6), "conservation units are a special type of protected area, created by the public power, under a special administration regime to which adequate guarantees of protection apply".

Thus, for eco(tourism) to be developed in a Conservation Unit, it is necessary, first, that public use is allowed in it. The current format for public use in Conservation Units began in the 1970s, aiming to meet the demands of society that envisioned the enjoyment of these areas, through environmental education and recreation activities in accordance with Pires \& Rugine (2018).

Corroborating with the thematic Canto-Silva \& Silva (2017) warn that public use allows the valorization of these spaces, reducing possible territorial conflicts resulting from their creation and, still, the resources obtained by the visitation promote collective benefits for the local populations, with the offering new jobs and increasing income.

The Parks are those Conservation Units, whose basic objective is to preserve the nature, freeing it, as much as possible, from human interference; in them, as a rule, only the indirect use of nature resources is admitted, (Pires \& Rugine, 2018).

According to data from the State Forestry Institute IEF (2015) the parks represents the oldest UC category and are created for the purpose of preserve native fauna and flora, mainly endangered species, water resources (springs, rivers, waterfalls), geological formations; conserve cultural, historical and archaeologi- cal values and promote scientific studies and research, environmental education and ecological tourism.

The National Parks (PARNA's) are the main category of Conservation Units, in terms of visitation. They are created by the federal government and have the Chico Mendes Institute for Biodiversity Conservation (ICMBio) as responsible for their management according to ICMBio (2020).

The creation of units in the Park category when carried out by the State or Municipality are called, respectively, State Park (PE) and Municipal Natural Park (PNM), with the state and municipal governments being responsible for their respective management. Law 9.985/2000, which establishes the SNUC, recommends criteria and standards, aiming at the proper creation, implementation and management of Conservation Units in Brazil. This legal instrument contributes to the ordering of the various laws disposed on the different categories of management of UCS, be they federal, state or municipal.

One of the fundamental criteria established by SNUC was the implementation of the Management Plan in the Parks, in order to enable, among other issues, the planning and ordering of public use in these areas. However, 20 years have passed since the Law that instituted the SNUC and, still, there is great weakness in a considerable part of the Conservation Units, with regard to compliance with this item recommended by the legislation, thus being an important challenge to be overcome.

The absence of the Management Plan negatively impacts the occurrence of visitation in most Brazilian Parks. In this respect, another challenge for the Parks is related to the difficulties of physical infrastructure and management capacity of these protected areas, according to Canto-Silva \& Silva (2017). The study of the authors, still points to an increase in the number of visits to the Parks, in the case of National and State, reflected by the consolidation of visits to $\mathrm{Na}$ tional Parks. The authors also show that the Municipal Natural Parks contribute significantly to the increase in the number of visits to the Parks.

In this context, it appears that the increase in the number of visits to the Parks produced a positive effect on the economy, since in Souza \& Simões (2018, p. 13), it is verified that:

In 2018, the almost 12.4 million visits in UC generated an expense of about $R \$ 2.4$ billion in the municipalities that access the units. The total contribution of these expenses to the national economy was around 90 thousand jobs, $R \$ 2.7$ billion in income, $R \$$ 3.8 billion in value added to GDP and $R \$ 1.1$ billion in taxes.

It is noteworthy that this scenario has a multiplier effect on the economy of each location, since visiting 
the Conservation Units requires differentiated services, showing that the different sectors that make up the productive arrangement of tourism are interdependent.

In a UC, the environmental education activities that can be carried out are: school activities, preparation of pamphlets and information material, preparation of teaching materials, communication, research, exposure, support for visitors, trails, among others, according to Valenti et al (2012).

Environmental interpretation is part of environmental education and concerns activities carried out to better understand the natural and cultural environment in UCs or other locations that require the technique. Environmental interpretation is understood as "the way of representing the language of nature, natural processes, the interrelationship between man and nature, in a way that visitors can understand and value the environment and local culture" according to the MMA (2006, p. 10).

The most common activities of environmental interpretation are: trails, museums, information kiosks, descriptive panels, interpretive trails, signs or subtitles, lectures, visitors center, videos, website, games with recreational activities and training for drivers, according to Moreira (2014).

Lobo \& Simões (2009), Vallejo (2013) and Moreira (2014) recognize the benefits of environmental interpretation activities, as well as full visitation to UCs. However, to guarantee the conservation of biodiversity in the units, it is necessary to know the negative impacts caused by visiting the environments, aiming to minimize, control and avoid them. It is understood that the environmental impact refers to physical, chemical, biological and social changes in the environment, caused by human interference, by natural agents or by the combination of the two (Vallejo, 2013).

In terms of impacts derived from the public use of UCs, there are those that are most recurrent: in water, soil, vegetation, fauna and social. These impacts are directly related to the volume and frequency of visitation. It is noticed that a large number of frequent visitors generates more impacts of destruction of flora, damage to infrastructure, presence of garbage, alteration of animal behavior, compaction of trails, drainage problems of the trails and noise emission, for example. Thus, the impacts resulting from the large number of visitors are greater than those from small groups that visit the unit less frequently (Lobo \& Simões (2009) and Vallejo (2013)).

\section{Methodology}

The state of Amazonas is home to 22 Conservation Units categorized as Parks, of which ten are national, seven state and five municipal natural. It should be emphasized that in this work, in the sense of directing the research, it was decided to take a look at the Anavilhanas National Park.

Through a bibliometric analysis of the publications of articles indexed in the database of SciELO - Scientific Electronic Library Online and SPELL - Scientific Periodicals Electronic Library, it was possible to understand about the approaches to the theme of Conservation Units and, in particular, about the Anavilhanas National Park and their interactions. The filter was made on this thematic, since the Anavilhanas National Park is the case that presents the characteristics that are covered by the legislation referring to the Conservation Units (UC's), as well as the one that still manages in an embryonic way, beyond legislative enforcement, to capture the insertion of the surrounding community, which can assure the assumptions of paths for a sustainable management.

Bibliometric research is a technique used to measure scientific knowledge. Pritchard (1969) defines bibliometrics as the study that tries to quantify the processes of written communication. Saes (2000, p. 10) adds that there are two reasons for using this technique,

the first to analyze the size, growth and distribution of the scientific bibliography (books, magazines, patents and others), in order to improve the activities of information, documentation and scientific communication and the second to analyze the processes of generation, propagation and use of scientific literature in order to understand the mechanisms of scientific research as a social activity and the dynamics and structure of the groups of researchers who produce and use this literature.

Publications, authors, keywords, citations and journals are some of the variables analyzed by this type of research. For a more careful analysis, some bibliometric laws were developed, with Bufrem \& Prates (2005) highlighting Bradford's Law - which measures the productivity of journals, Lotka's Law - which quantifies the scientific productivity of authors and Zipf's Law which measures the frequency of words, as being the most used laws.

In order to achieve the objective regarding conservation and ecotourism units in Amazonas, a survey was carried out in the SCIELO database, from 22 to 02.26.2021, through an advanced search, using the word Anavilhanas as a search term, thirteen works were found. Of these, only three articles were considered, as they are the most recent publications, which occurred in the years 2012, 2013 and 2019. The other findings referred to a time lapse from 1980 to 2008 and therefore were not analyzed.

Also, in order to meet the objective proposed on the 27th and 28th of February, 2021, a search was carried out on the SPELL platform, also with the word Anavilhanas. Two investigations were found, one from 2013 and the other from 2019, both of which contributed greatly to the elaboration of this work, as they focused 
on the Anavilhanas National Park.

The research was carried out adopting the qualitative approach, centered on the legal documents that regulate the Conservation Units under study. The qualitative study is useful because it allows the study of difficult questions to be quantified and, in this way, bibliographic research procedures were applied in books, theses and dissertations, articles available on the internet and governmental and non-governmental websites. The study had an exploratory and descriptive character. Through exploratory research it was possible to verify, analyze and map the knowledge inherent to the themes investigated, in all its dimensions. The descriptive research made it possible to describe the findings from the investigation, according to Veal (2011).

\section{RESULTS}

\section{The Parks in the State of Amazonas}

The dynamics of tourism in conservation units is part of a broad discussion on the different forms of ownership and access to parks, and other protected areas.

The definition of Park is intertwined with the concept of Conservation Units of integral protection, whether in urban or rural perimeter, according to their location, demanding the management of the union, states or municipalities. the Brazilian Amazon, as well as throughout the national territory, the regulations for natural parks emanate from SNUC, which defines the categories for the management areas, including the Environmental Protection Area - APA - in which are inserted the National Park, the State and the Natural Municipal, according to MMA (2020).

It is worth mentioning that among the National Parks located in the State of Amazonas - three do not have a Management Plan. Among the State Parks, in four of them there is also no Management Plan and in the Municipal Natural Parks only one of them is in the same condition, according to the CNUC (2020). The absence of this regulatory instrument may compromise the progress in the governance process of these parks, considering that the Plan has the functions of evaluating, directing and monitoring the performance of public management (BRASIL, 2014).

\section{National Parks}

Table 1 (one) shows the national parks of the state of Amazonas. These Conservation Units are shared with other states, with the exception of the Acari National Park, located in the municipality of Apuí, in Amazonas.

Table 1: National Parks of the State of Amazonas

\begin{tabular}{|c|c|c|c|c|c|c|}
\hline Covering municipalities & $\begin{array}{l}\text { Federation } \\
\text { Units }\end{array}$ & $\begin{array}{c}\text { Creation } \\
\text { Year }\end{array}$ & Park Name & $\begin{array}{c}\text { Hectares } \\
\text { Area }\end{array}$ & $\begin{array}{l}\text { Management } \\
\text { Plan } \\
\end{array}$ & $\begin{array}{c}\text { SNUC } \\
\text { Registration }\end{array}$ \\
\hline Apuí & Amazonas & 2016 & $\begin{array}{c}\text { Acari National } \\
\text { Park }\end{array}$ & 896.436 & No & Yes \\
\hline $\begin{array}{c}\text { Apuí and Maués (AM), } \\
\text { Cotriguaçu, Nova } \\
\text { Bandeirantes and Apiacás } \\
\text { (MT) }\end{array}$ & $\begin{array}{c}\text { Amazonas } \\
\text { Mato Grosso }\end{array}$ & 2006 & $\begin{array}{c}\text { Juruena National } \\
\text { Park }\end{array}$ & 1.956 .585 & Yes & Yes \\
\hline $\begin{array}{c}\text { Barcelos (AM), Caracaraí } \\
\text { (RR) }\end{array}$ & $\begin{array}{l}\text { Amazonas } \\
\text { Roraima }\end{array}$ & 1998 & $\begin{array}{c}\text { Serra da } \\
\text { Mocidade } \\
\text { National Park }\end{array}$ & 359.391 & Yes & Yes \\
\hline $\begin{array}{c}\text { Barcelos, Codajás and Novo } \\
\text { Airão } \\
\end{array}$ & Amazonas & 1980 & Jaú National Park & 2.367 .340 & Yes & Yes \\
\hline $\begin{array}{l}\text { Canutama and Lábrea } \\
\text { (AM), Porto Velho (RO) }\end{array}$ & $\begin{array}{l}\text { Amazonas } \\
\text { Rondônia }\end{array}$ & 2008 & $\begin{array}{l}\text { Mapinguari } \\
\text { National Park }\end{array}$ & 1.776 .926 & No & Yes \\
\hline $\begin{array}{l}\text { Maués (AM) } \\
\text { Aveiro and Itaituba (PA) }\end{array}$ & $\begin{array}{l}\text { Amazonas } \\
\text { Pará }\end{array}$ & 1974 & $\begin{array}{c}\text { Amazônia } \\
\text { National Park }\end{array}$ & 1.066 .302 & Yes & Yes \\
\hline
\end{tabular}

Source: Elaborated by the authors $(2021)^{2}$.

In 
Table 1: National Parks of the State of Amazonas

\begin{tabular}{c|c|c|c|c|c|c} 
Novo Airão and Manaus & Amazonas & 1981 & $\begin{array}{c}\text { Anavilhanas } \\
\text { National Park }\end{array}$ & 350.236 & Yes & Yes \\
\hline $\begin{array}{c}\text { Novo Aripuanã and } \\
\text { Manicoré (AM), } \\
\begin{array}{c}\text { Machadinho D'Oeste (RO), } \\
\text { Colniza (MT) }\end{array}\end{array}$ & $\begin{array}{c}\text { Amazonas } \\
\text { Rondônia } \\
\text { Mato Grosso }\end{array}$ & 2006 & $\begin{array}{c}\text { Campos } \\
\text { Amazônicos } \\
\text { National Park }\end{array}$ & 961.311 & Yes & Yes \\
\hline $\begin{array}{c}\text { São Gabriel da Cachoeira } \\
\text { and Santa Isabel do Rio } \\
\text { Negro }\end{array}$ & Amazonas & 1970 & $\begin{array}{c}\text { Pico da Neblina } \\
\text { National Park }\end{array}$ & 2.247 .228 & No & Yes \\
\hline Tapauá and Beruri & Amazonas & 2008 & $\begin{array}{c}\text { Nascentes do } \\
\text { Lago Jari National } \\
\text { Park }\end{array}$ & 812.742 & Yes & Yes \\
\hline
\end{tabular}

Source: Elaborated by the authors $(2021)^{2}$.

The territoriality of these Units is significant. The largest extension is the Jaú National Park, which has 2.367.340 hectares. It is the largest national park in Brazil and the largest park in the world in semi-humid and intact rainforest. The name Jaú, which comes from the Tupi language, names one of the largest Brazilian fish and also the river that bathes the Park. The region constitutes an important sample of Amazonian ecosystems, according to Silva (2014).

Pico da Neblina is the highest point in Brazil with 2,995.3 meters of altitude (IBGE, 2016). The park was created with the aim of protecting a significant sample of Amazonian ecosystems. Its conservation is indispensable. There are 46 indigenous communities located in these lands that are home to a great sociodiversity, according to Ribas (2018).

As shown in Table 1, the size of the national parks expresses the territoriality of Amazonas. The territorial grandeur of the region is also presented through the space that is contemplated in other parks, for example: a) Juruena; b) Mapinguari; c) the Amazônia; d) the Campos Amazônicos; e) Acari; f) Lago do Jari; g) Serra da Mocidade; h) Anavilhanas.

The Anavilhanas fluvial archipelago is the attribute that best defines the Park, occupying more than 210 thousand hectares ( $60 \%$ of its area), including an approximate $130 \mathrm{~km}$ long and $20 \mathrm{~km}$ wide stretch of the lower Negro River. With administrative headquarters in Novo Airão, Anavilhanas National Park is a tourist destination with easy access from Manaus and offers different attractions and experiences. During the floods, the water strolls in the igapós and, in the dry season, long beaches stand out. However, throughout the year, interaction tourism with dolphins, water rides, land trails and overflights allow recreation, sports, contemplation and knowledge activities, according to MMA (s.d).

\section{States PARKS}

Table 2 (two) lists the state parks in the state of Amazonas. In this case, the scope for sharing between other municipalities or states is smaller. In this way, it is noted that in Apuí is where the Sucunduri state park is located, and where the oldest geological domains of the Apuí mosaic are. This factor generates a different configuration in the local relief, marked by the presence of plateaus among the Amazon depression, and for this reason also known as Chapadas da Amazônia ${ }^{3}$.

Part of these parks is also characterized by overlapping with indigenous lands, such as Serra do Araçá and Matupiri. In the case of Parest Guariba, there is a concentration of a great variety of mosaic habitats, with terra firme forests, flooded forests, rupestrian fields, meadows and campinaranas, and the enormous scenic beauty provided by the falls and rapids. The rapids of Monte Cristo and the falls of the Sucunduri River are among the best-known landscapes for their attractive charm ${ }^{4}$.

Parest Sumaúma is located in one of the most populous areas of the urban perimeter of Manaus, it is one of the few protected urban forest fragments. Two sources within the park form a tributary of the Igarapé do Mindú, which crosses the city. According to Oliveira (2012), Sumaúma can serve as a showcase for the Conservation Units of the State of Amazonas. The fact that it is located in the urban area, has a strong appeal to public visitation, is an ideal space for environmental education in schools in Manaus, especially those located in the northern part of the city, should be seen as an opportunity.

In Parest Rio Negro North Section, about 30 families live in the vicinity of the Park, with the most inhabited communities being those of Castanho and Airão Velho, where the ruins of the first portuguese city on the $\mathrm{Ne}$ - 
gro River, from the 16 th century. The main access is by boat, through the Negro River. A good part of the families residing in the Park lives exclusively from agriculture, especially from the cultivation of cassava and bananas. The majority of the resident population is descended from indigenous ethnicities. The Park receives tourist visitation in boats from tour operators, still practiced in an unorganized way. ${ }^{6}$

Table 2: State Parks of the State of Amazonas

\begin{tabular}{c|c|c|c|c|c}
\hline Covering municipalities & $\begin{array}{c}\text { Creation } \\
\text { Year }\end{array}$ & Park Name & Hectares Area & $\begin{array}{c}\text { Management } \\
\text { Plan }\end{array}$ & $\begin{array}{c}\text { SNUC } \\
\text { Registration }\end{array}$ \\
\hline Apuí & 2005 & $\begin{array}{c}\text { Sucunduri State } \\
\text { Park }\end{array}$ & $808.312,18$ & No & Yes \\
\hline Barcelos & 1990 & $\begin{array}{c}\text { Serra do Araçá } \\
\text { State Park }\end{array}$ & $1.818 .700,00$ & Yes \\
\hline Borba and Manicoré & 2009 & $\begin{array}{c}\text { Matupiri State } \\
\text { Park }\end{array}$ & $513.747,47$ & Yes & Yes \\
\hline Manaus & 1995 & $\begin{array}{c}\text { Rio Negro State Park } \\
\text { South Section }\end{array}$ & $77.950,85$ & Yes \\
\cline { 2 - 7 } & 2003 & $\begin{array}{c}\text { Sumaúma State } \\
\text { Park }\end{array}$ & 52,62 & Yes & Yes \\
\hline Manicoré & 2005 & $\begin{array}{c}\text { Guariba State } \\
\text { Park }\end{array}$ & $72.296,33$ & No & Yes \\
\hline Novo Airão and Manaus & 1995 & $\begin{array}{c}\text { Rio Negro State Park } \\
\text { North Section }\end{array}$ & $146.028,00$ & Yes & Yes \\
\hline
\end{tabular}

Source: Elaborated by the authors $(2021)^{5}$.

\section{Municipal Parks}

In this section there is an approach related to municipal parks in the state of Amazonas. In the context of the municipality of Manaus, there is (i) the Mindú Municipal Park, created in 1993 and (ii) the Nascentes do Mindú Municipal Park, created in 2006.

Manaus is a city with an abundance of waters. In addition to the Negro River, which flows through its bank, there are small riverbeds that cut and cut out the city. As the city grows, the human agglomeration resulting from disorderly migration has contributed, among other factors, to the loss of the quality of these waters.

In the past, the igarapés have supplied the needs of the population, both through navigation and by supplying the residents, however, they gradually disappeared and were transformed into streets and avenues in the city. This urbanization process started to provide a visible distance between society and nature, while cities become spaces with increasingly artificial forms, according to Albuquerque \& Molinare, (2020), Silva \& Lima (2008) and Duarte et al (2017).

Among the purposes in creating the site was to protect and preserve the existing ecosystems at the headwaters of the Igarapé do Mindú, guarantee the protection of the environmental attributes of the place and promote the integration of the community surrounding the park in socio-environmental and educational activities, according Santos (2019).

Presidente Figueiredo is served by three municipal conservation units categorized as Parks, namely: (i) the Galo da Serra Municipal Natural Park; ; (ii) the Orquídeas Municipal Natural Park and (iii) the Urubuí Municipal Natural Park.

\section{THE ANaVilhanas Park}

The state of Amazonas includes ten National Parks, among which the Anavilhanas is the one with the smallest territorial area (CNUC, 2020) However, this Park is home to the second largest river archipelago in the world, the Anavilhanas archipelago, formed by 400 islands, 60 lakes, several paranás and boreholes, according to Araújo Silva \& Simonetti (2020).

The public use in Conservation Units (UCs), mainly through visitation, can bring direct and indirect benefits to society. Parks are very favorable areas for visitation, providing visitors with the opportunity to know, understand and value the natural and cultural resources existing in these areas, contributing to the local socioeconomic development. 
Table 3 - Municipal Parks of the State of Amazonas

\begin{tabular}{|c|c|c|c|c|}
\hline $\begin{array}{c}\text { Covering } \\
\text { municipalities }\end{array}$ & $\begin{array}{c}\text { Creation } \\
\text { Year }\end{array}$ & Park Name & $\begin{array}{l}\text { Management } \\
\text { Plan }\end{array}$ & SNUC Registration \\
\hline \multirow[t]{2}{*}{ Manaus } & 1993 & $\begin{array}{l}\text { Mindú Municipal } \\
\text { Park }\end{array}$ & Yes & No \\
\hline & 2006 & $\begin{array}{l}\text { Nascentes do Mindú } \\
\text { Municipal Park }\end{array}$ & Yes & No \\
\hline \multirow[t]{3}{*}{$\begin{array}{l}\text { Presidente } \\
\text { Figueiredo }\end{array}$} & 2002 & $\begin{array}{c}\text { Galo da Serra } \\
\text { Municipal Natural Park }\end{array}$ & Yes & No \\
\hline & 2002 & $\begin{array}{c}\text { Orquídeas Municipal } \\
\text { Natural Park }\end{array}$ & Yes & No \\
\hline & 2009 & $\begin{array}{l}\text { Urubuí Municipal } \\
\text { Natural Park }\end{array}$ & Yes & No \\
\hline
\end{tabular}

Source: Elaborated by the authors $(2021)^{8}$.

The knowledge of the panorama in which the visitation takes place in Brazilian Parks, as well as the conduct of visitors, is an important exercise in ordering this visitation. Thus, it is of fundamental importance for the management of public use, growing in these areas, and for the assessment of the impact of the activity on local communities, in the analysis of Canto-Silva \& Silva (2017).

Novo Airão is the headquarters of the Anavilhanas National Park (AM) and is one of the natural destinations sought by visitors who seek to know its beauty and attractions, associated with leisure and well-being, provided by the preserved natural environment of the many islands that form the archipelago. In this context, visitation in the Park becomes an important tool for the management and conservation of biodiversity (Silva, 2019). In figures $1 \mathrm{a}$ and $1 \mathrm{~b}$ it is possible to see aerial images of Anavilhanas Park.
Figure 01: Anavilhanas National Park

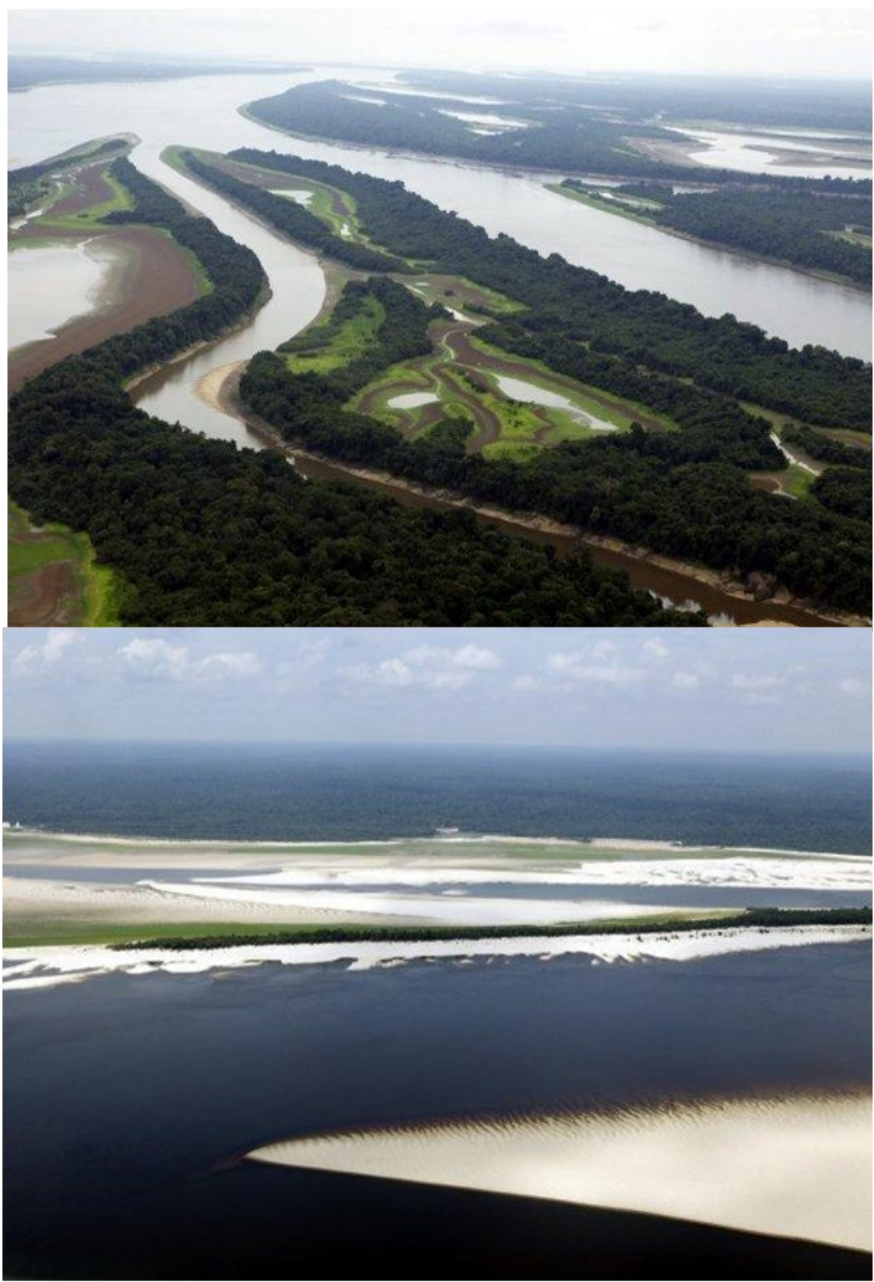

Source: ICMBio - Visitor's Guide, year 2020 
Anavilhanas National Park has been the subject of studies for many researchers. In order to identify the recurrence of the approaches of these investigations, we searched the Scielo and Spell databases where the works (01 to 03 ) and (04 and 05), respectively listed, were found, where the focus of research and authorship stands out, as Table 4.

Table 4: Investigations related to Anavilhanas Park in Scielo and Spell databases

\begin{tabular}{|c|c|c|c|}
\hline Article focus & Authors & $\begin{array}{c}\text { Type / } \\
\text { Data } \\
\text { Collection }\end{array}$ & $\begin{array}{c}\text { Year } \\
\text { Source }\end{array}$ \\
\hline $\begin{array}{l}\text { To present the perception of local } \\
\text { inhabitants about the socioeconomic and } \\
\text { conservation impacts of interactive } \\
\text { tourism with dolphins on the Amazon } \\
\text { River. }\end{array}$ & $\begin{array}{c}\text { Marcelo Derzi Vidal } \\
\text { Urbano Lopes da Silva Junior } \\
\text { Priscila Maria da Costa Santos } \\
\text { Susy Rodrigues Simonetti } \\
\text { Maria do Perpétuo Socorro Rodrigues } \\
\text { Chaves }\end{array}$ & $\begin{array}{l}\text { Empirical } \\
\text { Interviews }\end{array}$ & $\begin{array}{l}\text { Viga. perspectivas tur. vol. } 28 \\
\text { no.3 Cidade Autônoma de } \\
\text { Buenos Aires jul. } 2019\end{array}$ \\
\hline $\begin{array}{l}\text { To present a detailed assessment of the } \\
\text { perception of the local community } \\
\text { regarding the possible socioeconomic } \\
\text { impacts of this tourism in Novo Airão. }\end{array}$ & $\begin{array}{c}\text { Luiz C.P.S. Alves } \\
\text { Camilah A. Zappes } \\
\text { Rafael G. Oliveira } \\
\text { Artur Andriolo } \\
\text { Alexandre De F. Azevedo }\end{array}$ & $\begin{array}{l}\text { Empirical } \\
\text { Interviews }\end{array}$ & $\begin{array}{l}\text { Anais Academia Brasileira de } \\
\text { Ciências vol.85 no.4 Rio de } \\
\text { Janeiro } 2013 \text { Epub Nov 10, } 2013\end{array}$ \\
\hline $\begin{array}{l}\text { Assess the diversity and distribution of } \\
\text { fish species in two habitats: flooded } \\
\text { forest and open water from lakes in the } \\
\text { Negro River. } \\
\text { Identify a profile of visitors to twotourist } \\
\text { sites and conservation units in the } \\
\text { Brazilian Amazon Basin: Tapajós National } \\
\text { Forest (Pará) and Anavilhanas National } \\
\text { Park (Amazonas). }\end{array}$ & $\begin{array}{l}\text { Janette Noveras } \\
\text { Kedma C. Yamamoto } \\
\text { Carlos E.C. Freitas } \\
\text { Robert Clyde Burns } \\
\text { Lidiane Castro Gregory } \\
\text { Jasmine Cardozo Moreira }\end{array}$ & $\begin{array}{c}\text { Empirical } \\
\text { Fish sampling } \\
\text { Empirical } \\
\text { Quiz }\end{array}$ & $\begin{array}{l}\text { Acta Amaz. Vol.42 } \\
\text { no. } 4 \\
\text { Manaus, } 2012 \\
\text { Marketing \&. Tourism Review } \text {. } \\
\text { Belo Horizonte - MG - Brasil • v. } \\
\text { 4, n. 1, ago, } 2019\end{array}$ \\
\hline $\begin{array}{l}\text { Identify the profile of the visitors of the } \\
\text { Floating of the dolphins and their } \\
\text { perceptions about the interactive tourism } \\
\text { with the cetaceans in the Anavilhanas } \\
\text { National Park. }\end{array}$ & $\begin{array}{c}\text { Marcelo Derzi Vidal } \\
\text { Priscila Maria da Costa Santos } \\
\text { Camila Vasconcelos de Oliveira } \\
\text { Lara Clímaco de Melo }\end{array}$ & $\begin{array}{l}\text { Empirical } \\
\text { Interviews }\end{array}$ & $\begin{array}{l}\text { Revista Brasileira de Pesquisa em } \\
\text { Turismo. São Paulo, 7(3), pp. 419- } \\
435 \text {, set./dez. } 2013\end{array}$ \\
\hline $\begin{array}{l}\text { Evaluate the tourist attractions of the } \\
\text { Anavilhanas National Park (AM) through } \\
\text { a matrix, ranking their attractions in } \\
\text { relation to: infrastructure, state of } \\
\text { conservation, access, degree of use, local } \\
\text { and community support, to create a } \\
\text { ranking of attractions. }\end{array}$ & $\begin{array}{l}\text { Mayara de Araújo Silva } \\
\text { Suzy Rodrigues Simonetti }\end{array}$ & $\begin{array}{l}\text { Interviews } \\
\text { Quiz }\end{array}$ & $\begin{array}{l}\text { Revista Brasileira de Ecoturismo } \\
\text { (RBEcotur), } 13 \text { (1) } 2020 .\end{array}$ \\
\hline
\end{tabular}

Source: Elaborated by the authors $(2021)^{9}$ 
In The data expressed in table 4 demonstrate that despite the low number of articles on Anavilhanas Park, there is a diversity of approaches on topics such as: a) the socioeconomic impacts on flora / fauna; b) the community's perception of the park; c) aspects related to visitation.

In the work carried out by Araújo Silva \& Simonetti (2020) it is noted that Brazilians are the main visitors of the Park, with the majority coming from the state of Amazonas itself, due to the proximity of Anavilhanas to the surrounding municipalities, such as Novo Airão, Manacapuru, Iranduba and the capital Manaus. Data from ICMBio (2020) show that Anavilhanas received, in 2019, a number of visits corresponding to four times that of the Jaú National Park, which is the largest in the State of Amazonas.

The decision of a tourist activity for a park is the result, among other aspects, of an action driven by curiosity. In the case of Anavilhanas Park, this becomes more expressive due to the possibilities of perception that it provides to the visitor.

Thus, it is important to note that the different plant formations, combined with river dynamics, contribute to the high biodiversity and endemism of the archipelago. In Anavilhanas, about 500 species of fish were registered, as well as several species of birds, insects and large animals. The park is home to species such as the manatee (Trichedus iniguis), the jaguar (Harpia harpyja), the pirarucu (Arapaina gigas), red dolphins (Inia geoffrensis), tucuxis (Sotalia fluviatilis), otters (Lutra longicaudis), giant otters (Pteronura brasiliensis), giant anteater (Myrmecophaga trytactyla), tapir (Tapitus terrestre) and several species of turtles and alligators (Alves et al, 2013).

Due to the dynamics of the waters in the Amazon region, two scenarios stand out in the Anavilhanas Park: the period of drought (ebb from rivers) and flood. In this way, according to $\mathrm{ICMBio}^{10}$, in the dry season (September to February) it is possible to enjoy the beautiful white sand beaches that emerge throughout the archipelago. In the flood (March to August) the glimpse is due to the water trails of igapó, that is, boat trips through the flooded forests. At any time it is possible to visit the Dolphins Float, enjoy the rich Amazonian flora and fauna, take boat trips through one of the largest river archipelagos in the world, take terrestrial trails, bathe in the beautiful waters of the Negro River, meet traditional riverside communities and the beautiful craftsmanship of Novo Airão, among other attractions.

Extracted from ICMBio (2017), we have to follow the guidelines of Ordinance $n^{\circ} 47$ of 04/09/2012 that regulates the activities and attractions developed in the Anavilhanas National Park.
Land trails: hiking trails in the middle of the Terra Firme Forest, where you can find centenary and large trees, species with commercial and medicinal value and a diverse floristic composition.

I) Apuau Trail;

II) Barro Branco Trail; and

II) Bariau Trail.

Water trails: They consist of trails along rivers, small channels (holes, paranás and igarapés) and, in the flood, also through the archipelago's igapós to be traveled on boarding's (motorized or not). They may include breaks in the routes of the aquatic tours, with observation of the local fauna and flora on the islands, without necessarily following a terrestrial trail, just a contemplation, close to the island's edge.

Beaches of the Archipelago and the Orla de Novo

Airão: They refer to several beaches, which are formed during the dry season (September to February) along the archipelago, in addition to the Orla de Novo Airão Beach, are widely used for leisure and recreation from the local residents and visitors.

I) Aracari;

II) Baranoá;

III) Camaleão;

IV) Folharal/Canauiri;

V) lluminado;

VI) Meio;

VII) Sobrado; and

VII) Tiririca.

Stop at the Islands: the landings at the islands for observation of fauna, flora and landscape were planned at the following locations:

I) Parana of Shrimp,

II) Hole of Ambe,

III) Hole of Apacuzinho,

IV) Hole of Apuí,

V) Mosquito / Stingray Hole,

VI) Parana of Jaguar,

VII) Lake of Tamuatá and

VIII) Lake of Uruá.

Fauna Observation: the observation of the local fauna occurs in terrestrial or aquatic environment, day or night, usually accompanied by a local guide or driver. Noteworthy is the interaction tourism with red dolphins in the floating dolphin, located on the edge of Novo Airão, the main tourist attraction of the Anavilhanas National Park and the city. The Anavilhanas National Park is a pioneer in organizing this activity in Brazil.

Panoramic flight: possibility of aerial contemplation of the Anavilhanas National Park landscape. According to the Ordinance, landings would be allowed only in the river portion of the Park.

In this way, Anavilhanas Park plays a significant role as holder of natural resources of this scope. The natural and cultural environment are the main components of 
ecotourism, so planning and management for the rational use of the resources available in these environments should be the main premise, when the objective is their exploration, according to Filetto \& Macedo (2015).

Ceballos Lascuráin (1996) was the first theorist to use the term ecotourism, according to him what differentiates ecotourism from other types of Nature Tourism is the application of ethical values to tourist behavior, emphasizing the concept of sustainability with development and the educational character.

The concept of ecotourism has evolved over the years to give man greater responsibility in relation to the environment he visits. That said, the definition of ecotourism proposed by the World Tourism Organization, (UNWTO, 2018) has the following characteristics

1. All forms of tourism based on nature where the main motivation of tourists is the observation and appreciation of nature and also of the traditional cultures that prevail in natural areas.

2. It contains educational and interpretation resources.

3. It is usually, but not exclusively organized by specialized tour operators for small groups. Service provider partners in destinations tend to be small, locally owned businesses.

4. Minimizes negative impacts on the natural and socio -cultural environment.

5. Supports the maintenance of natural areas that are used as attractions for ecotourism by: a) Generating economic benefits for host communities, organizations and authorities that manage natural areas for conservation purposes; b) Provide alternative employment and income opportunities for local communities; and c) Increase awareness of the conservation of natural and cultural assets, both among residents and tourists.

For ecotourism to be well developed in a given location, whether or not it is a Conservation Unit, it needs to adapt to the four fundamental principles of the activity.

The first principle of ecotourism refers to the financial commitment to nature conservation. In this sense, the collection made through visitation can be an important source of funding for the demands of the UC area itself, such as aid in the conservation of the place, in addition to bringing, Vallejo (2013, p. 8) states that: "[...] greater financial movement, including the collection of taxes and the growth of commercial activities for the localities [...] generating collective benefits, especially in the case of offering new jobs and an increase in income for the local population".

The insertion of local communities and traditional populations is a fundamental principle of ecotourism, it is also one of the characteristics that differentiate ecotourism from nature tourism. The Ministry of the Environment (2006) determines guidelines for the participation of local communities and traditional populations in a UC. It also determines, among other things, the development of information, awareness and environmental education campaigns that can bring the local population of the UC closer together and awaken feelings of respect and responsibility towards the area (MMA, 2006, p.19).

The diffusion of ecological values is characterized as the third principle of ecotourism and must be propagated through environmental education and interpretation. Environmental education is understood as the processes through which the individual and the community build social values, knowledge, skills, attitudes and competences aimed at the conservation of the environment (Bueno \& Pires, 2006).

In a Conservation Unit, the environmental education activities that can be carried out are: school activities, preparation of pamphlets and information material, preparation of teaching materials, communication, research, exhibition, support for visitors, trails, among others, according to Valenti et al (2012).

Environmental interpretation is part of environmental education and concerns activities carried out to better understand the natural and cultural environment in UCs or other locations that require the technique. Environmental interpretation is understood as "the way of representing the language of nature, natural processes, the interrelationship between man and nature, in a way that visitors can understand and value the environment and local culture" in the analysis of the MMA (2006, p 10).

Lobo and Simões (2009), Vallejo (2013) and Moreira (2014) recognize the benefits of these activities, as well as of visiting the UCs as a whole, however, to ensure the conservation of biodiversity in the units, it is also necessary to know the negative impacts caused by visitation to environments, aiming to minimize, control and avoid them.

The last principle concerns the concern with the environmental impacts caused at the destination. It is understood that the environmental impact refers to physical, chemical, biological and social changes in the environment, caused by human interference, by natural agents or by the combination of the two, in agreement with Vallejo (2013).

\section{Final Consideration}

The research path that gave rise to this article allowed us to understand how the activity resulting from ecotourism is part of a process of preservation and maintenance of the natural resources that make up the Amazonian environment.

The protection of Conservation Units (UC's) is an action that includes the internal and external view of interested parties, involving nature, the State, the surrounding 
community, among others, in order to achieve the objective of preservation both present and future generations.

In this way, the research results showed that natural wealth, in terms of park offerings, represents a tool that provides, in sustainable and ecotourism terms, options for using this resource, since the location of these units covers a given sphere, whether in municipal, state or national territory, as it was exposed and these communities can be benefited.

Anavilhanas is a natural treasure that has demonstrated how much sustainability, if well managed from an aspect of governance, can be a beautiful ally. The activity of ecotourism, although not the only alternative of economic development for the localities, allows conditions to reduce the pressure on natural resources.

In this context, the importance of regional tourism governance is seen, whose primary function is to act in favor of its region in a cohesive manner, in which its actors cooperate and carry out joint and transparent actions for the improvement and development of their regions, according to Conceição (2020, p. 3).

Given the importance of the Anavilhanas National Park and considering that the present work was dedicated to making brief considerations about this Park, it is possible to develop in future research the demonstration of what is recommended in the protection legislation for these Conservation Units with the reality of the Park.

It is also possible to identify the profile of visitors to the National Parks under the intention of knowing the reasons for visiting each one, as the tourist decision is a planned action and that, at times, has a subjective incentive for its implementation.

\section{REFERENCES}

Albuquerque, N. Ramos; Molinari, D. C. (2020). Caracterização da Cobertura Vegetal no Alto Curso da Bacia do Igarapé do Mindu - Manaus (AM). Revista Brasileira de Geografia Física 13(01), 406-422.

Alves, N. S. (2013). Mapeamento hidromorfodinâmico do complexo fluvial de Anavilhanas. Contribuição aos estudos de geomorfologia fluvial de rios Amazônicos. Universidade de São Paulo. (Tese de Doutorado). Programa de Pós Graduação em Geografia Física. São Paulo.

Araujo Silva, M. de, \& Simonetti, S. R. (2020). Avaliação dos atrativos turísticos do Parque Nacional de Anavilhanas (AM). Revista Brasileira De Ecoturismo (RBEcotur) 13 (1). https://doi.org/10.34024/rbecotur.2020.v13.6791

Bueno F.; Pires. P. (2006). Ecoturismo e educação ambiental: possibilidades e potencialidades de conservacão da natureza. IV SeminTUR - Seminário de Pesquisa em Turismo do MERCOSUL Universidade de Caxias do Sul - Mestrado em Turismo Caxias do Sul, RS, Brasil.
Bufrem, L: Prates Y. (2005) O saber científico registrado e as práticas de mensuração da informação. Ciência da Informação. Brasília, v. 34, n. 2, p. 9-25.

Cadastro Nacional de Unidades de Conservação. (2020). Recuperado de https://antigo.mma.gov.br/areasprotegidas/cadastro-nacional-de-ucs.html.

Canto-Silva, C. R. Silva, J. S. (2017). Panorama da visitação e da condução de visitantes em Parques brasileiros. Revista Brasileira de Pesquisa em Turismo, 11(2), 365-386.

Ceballos-Lascuráin, H. (1996) Tourism, Ecotourism and Protected Areas: The State of Nature-Based Tourism around the World and Guidelines for Its Development. IUCN Publications, Cambridge, 301.

Chaves, P. C. P. R. (2016). As Transformações no Trabalho e no Modo De Vida da Comunidade Bela Vista Do Jaraqui Manaus - Am. (Dissertação de Mestrado). Recuperado de https://tede.ufam.edu.br/handle/tede/5587

Conceição, C.C. (2020). Modelo analítico de governança regional de turismo - Magret. Revista Brasileira de Pesquisa em Turismo, São Paulo, 14(2), 123-138. Recuperado de http://dx.doi.org/10.7784/rbtur.v14i2.1822

Duarte, T.E.P. Angeoletto, F. H. S. Correa Santos, J. W. M. Leandro, D. da S., Copetti Bohrer, J. F., Vacchiano, M. C., Leite, L. B., (2017). O Papel da Cobertura Vegetal nos Ambientes Urbanos e sua Influência na Qualidade de Vida nas Cidades. Revista Desenvolvimento em Questão [online], 15.

Filetto, F., \& Macedo, R.L.G.I. (2015). Desenvolvimento de indicadores de sustentabilidade para o ecoturismo em unidades de conservação. Revista Brasileira de Ecoturismo, São Paulo, 8(1)

ICMBIO. (2020). Parques do Brasil, visitar é proteger. Estratégias de implementação da visitação em unidades de conservação federais: prioridades de execução 20182020. Coordenação Geral de Uso Público e Negócios/ Instituto Chico Mendes de Conservação da Biodiversidade. Brasília (DF). Recuperado de www.icmbio.gov.br.

ICMBIO. (2017). Plano de Manejo do Parque Nacional de Anavilhanas. Coordenação Geral de Uso Público e Negócios/Instituto Chico Mendes de Conservação da Biodiversidade. Brasília (DF). Recuperado de www.icmbio.gov.br

Instituto Brasileiro de Geografia e Estatística - IBGE. Recuperado de https://agenciabrasil.ebc.com.br/geral/ noticia/2016-02/ibge-reve-altitudes-de-sete-picosbrasileiros-pico-da-neblina-fica-mais-alto.

Instituto Chico Mendes de Conservação da Biodiversidade ICMBio. Monitoramento da visitação em Unidades de Conservação Federais: Resultados de 2019 e breve panorama histórico. Recuperado de https:// www.icmbio.gov.br/portal/images/stories/ comunicacao/publicacoes/ monitoramento_visitacao_em_ucs_federais_resultados_2019_breve_p anorama_historico.pdf

Instituto Estadual de Florestas de Minas Gerais - IEF. Recuperado de http://ief.mg.gov.br/component/content/ article/3306-nova-categoria/2836-parques-estaduais.

Lobo, A. C., \& Simões, L. L. (2009). Manual de monitoramento e gestão dos impactos da visitação em unidades de 
conservação. São Paulo: Secretaria de Meio Ambiente.

Ministério do Meio Ambiente - MMA. (2006). Diretrizes para a visitação em unidades de conservação. Brasília: Ministério do Meio Ambiente.

Ministério do Meio Ambiente - MMA. Áreas Protegidas. (2020). Recuperado de https://antigo.mma.gov.br/ areas-protegidas.html.

Ministério do Meio Ambiente - MMA. (2002). Lei $n^{\circ}$ 9.985, de 18 de julho de 2000. Regulamenta o art. $225, \S 10$, incisos I, II, III e VII da Constituição Federal, institui o Sistema Nacional de Unidades de Conservação da Natureza e dá outras providências e Decreto 4.340, de 22 de agosto de 2002. 3.ed. Brasília: Ministério do Meio Ambiente / Secretaria de Biodiversidade e Florestas.

Ministério do Meio Ambiente - MMA. (s. d) Plano Interpretativo Parque Nacional de Anavilhanas. Recuperado de https://pdf.usaid.gov/pdf_docs/PA00WH4W.pdf.

Moreira, J. C. (2014). Geoturismo e interpretação ambiental. ŚciELO-Editora UEPG.

Nogueira-Neto, P. (1991). Estações Ecológicas:Uma Saga de Política Ambiental. Empresa das Artes, Sao Paulo. $104 p$.

Oliveira, V. L. F. (2012). Subsídios para o plano de uso público do parques estadual Sumaúma. (Dissertação de Mestrado). Pós-Graduação em Gestão de Areas Protegidas na Amazônia. Instituto Nacional de Pesquisas da Amazônia (INPA). Manaus.

Pinto, A.M. (1894). Apontamentos para o diccionário geographico do Brazil. Imprensa Nacional, Rio de Janeiro $-R J .296 p$.

Pires, P.S.; Rugine; E, V.M.T. (2018). Reconhecimento do Uso Público nos Parques Estaduais no Brasil com ênfase na visitação turística. Revista Brasileira de Ecoturismo, São Paulo, 11(1), 61-80.

Pritchard, A. (1969). Statistical bibliography or bibliometrics? Journal of Documentation, v. 25, n. 4, p. 348-349.

Ribas, R M. (2018). Análise da Paisagem do Parque Nacional Pico da Neblina - Am, baseado em dados secundários de sensoriamento remoto. (Monografia de Graduação). Universidade Federal do Virçosa. Minas Gerais.

Rodrigues, C.G.O., Abrucio, F.L. (2019). Parcerias e concessões para o desenvolvimento do turismo nos parques brasileiros: possibilidades e limitacões de um novo modelo de governança. RBTUR, Sẵo Paulo, 13(3), 105120.

Saes. S.G. (2000). Estudo bibliométrico das publicações em economia da saúde, no Brasil 1989- 1998. (Dissertação) - Programa de Pós-Graduação em Administração, Serviços de Saúde, Faculdade de Saúde Pública Universidade de São Paulo.

Santos, R. M. L. (2019). Ecossistema Comunicacional aplicado à sistemática do Parque Municipal do Mindu. 2019. (Dissertação de Mestrado) Pós-Graduacão em Ciências da Comunicação. Universidade Federal do Amazonas, Manaus.

Scientific Eletronic Library Online- Scielo. Recuperado de https://scielo.org/.
Scientific Periodicals Eletronic Library- SPELL. Recuperado de http://www.spell.org.br/.

Secretaria do Meio Ambiente do Estado do Amazonas. Recuperado de: http://meioambiente.am.gov.br/parqueestadual/.

Silva, G. B. M. (2014). VIII - Gestão ambiental e desautorização dos moradores em RDS: reserva de desenvolvimento sustentável - do Rio Negro - AM. In: Neves, D. P. Gomes, R. A. e Leal, P. F., orgs. Quadros e programas institucionais em políticas publicas [online]. Campina Grande: EDUEPB, 219-240.

Silva، M. (2019). Avaliação dos Atrativos Turísticos do Parque Nacional de Anavilhanas (AM). (Dissertação de Mestrado). Pós-Graduação em Gestão de Áreas Protegidas na Amazônia. Instituto Nacional de Pesquisas da Amazônia (INPA). Manaus.

Silva, S. L., Lima, M. C, de. (2008). Impactos Socioespaciais da Intervenção Urbana aos Ribeirinhos da Cidade de Manaus AM. (Apresentação de Trabalho/Outra).

Sistema IBGE DE Recuperação Automática- SIDRA. Recuperado de: (https://sidra.ibge.gov.br/home/pimpfbr/ brasil)

Souza, T. V. S. B.: Simões, H. B.: (2018). Contribuicões do Turismo em Unidades de Conservação Federais para a Economia Brasileira - Efeitos dos Gastos dos Visitantes em 2017: Sumário Executivo. ICMBio. Brasília.

Unidades de Conservação no Brasil. Situação das Unidades de Conservação. Recuperado de https:// uc.socioambiental.org/.

UNWTO. Ecotourism and Protected Areas. Madrid: UNWTO (2018). Recuperado de https://www.unwto.org/ sustainable-development/ecotourism-and-protectedareas.

Valenti, M. W., Oliveira, H. D., Dodonov, P., \& Silva, M. M. (2012). Educação ambiental em unidades de conservação: políticas públicas e a prática educativa. Educação em Revista, 28(01), 267-288.

Vallejo, L. R. (2013). Uso público em áreas protegidas: atores, impactos, diretrizes de planejamento e gestão. Revista Eletrônica Anais Uso Público em Unidades de Conservação, 1(1), 13-26.

Veal, A. J. (2011). Metodologia de pesquisa em lazer e turismo. São Paulo: Aleph. 